\title{
Relationship between Carbon Stock and Plant Biodiversity in Collaborative Forests in Terai, Nepal
}

\author{
Ram Asheshwar Mandal, ${ }^{1}$ Ishwar Chandra Dutta, ${ }^{2}$ \\ Pramod Kumar Jha, ${ }^{3}$ and Siddhibir Karmacharya ${ }^{1}$ \\ ${ }^{1}$ Tirchandra College, Kathmandu, Nepal \\ ${ }^{2}$ Tribhuvan University Commission, Kirtipur, Kathmandu, Nepal \\ ${ }^{3}$ Central Department of Botany, Tribhuvan University, Kirtipur, Nepal \\ Correspondence should be addressed to Ram Asheshwar Mandal; ram.mandal@gmail.com
}

Received 20 April 2013; Accepted 28 May 2013

Academic Editors: C. Bolle, F. A. Culianez-Macia, J. H. Titus, and J.-K. Weng

Copyright (C) 2013 Ram Asheshwar Mandal et al. This is an open access article distributed under the Creative Commons Attribution License, which permits unrestricted use, distribution, and reproduction in any medium, provided the original work is properly cited.

\begin{abstract}
Reducing emission from deforestation and forest degradation (REDD+) programme has prime concern to carbon stock enhancement rather than biodiversity conservation. Participatory managed forest has been preparing to get benefit under this programme, and collaborative forest is one of them in Nepal. Hence, this research is intended to assess the relationship between carbon stock and biodiversity. Three collaborative forests (CFMs) were selected as study sites in Mahottari district, Nepal. Altogether 96 sample plots were established applying stratified random sampling. The plot size for tree was $20 \mathrm{~m} \times 25 \mathrm{~m}$. Similarly, other concentric plots were established. Diameter at breast height (DBH) and height were measured, species were counted, and soil samples were collected from $0-0.1,0.1-0.3$, and $0.3-0.6 \mathrm{~m}$ depths. The biomass was calculated using equation of Chave et al. and converted into carbon, soil carbon was analyzed in laboratory, and plant biodiversity was calculated. Then, relation between carbon stock and biodiversity was developed. Estimated carbon stocks were 197.10, 222.58, and 274.66 ton ha ${ }^{-1}$ in Banke-Maraha, Tuteshwarnath, and Gadhanta-Bardibas CFMs, respectively. The values of Shannon-Wiener Biodiversity Index ranged 2.21-2.33. Any significant relationship between carbon stock and biodiversity, and was not found hence REDD+ programme should emphasize on biodiversity conservation.
\end{abstract}

\section{Introduction}

Halting deforestation single can contribute to reduce about $18 \%$ atmospheric $\mathrm{CO}_{2}$ emission [1]. Thus the forest management has objectively been focused on altering the deforestation and forest degradation targeting to get the benefit from reducing emission from deforestation and forest degradation (REDD+) programme in response to climate change [2]. Community managed forests also have been preparing to be candidate under this [3]. Simultaneously, other important part under this programme is biodiversity conservation and promotion.

Deforestation contributes about $5.9 \mathrm{GtCO}_{2}$ annually in the world [4]. The current rate of deforestation, clearing tropical forests could release an additional 87 to $130 \mathrm{GtC}$ of $\mathrm{CO}_{2}$ to the atmosphere by 2100 [5]. In the base year 1994/1995, net emissions of $\mathrm{CO}_{2}$ from all sectors in Nepal were estimated to be $9747 \mathrm{Gg}$ and from the land-use change and forestry sectors were about $8117 \mathrm{Gg}$ [6].

Collaborative forest is the management of the forests by three different collaborators-district forest office, district development institutions, and users including distant users. The participation of distant users in forest management and benefit sharing mechanism is the key feature of collaborative forests. Though the main purpose of collaborative forest management is to meet the demand of forest products of users, this also offers to store and sequestrate forest carbon simultaneously. Statistically, about 305.11 million ha forest was managed by community based institutions specifically indigenous people in 36 countries, and in Asia-Pacific it was about 146.00 million ha [7]. In Nepal, there are about 17 collaborative forests managing 43445 ha of forests areas. As 


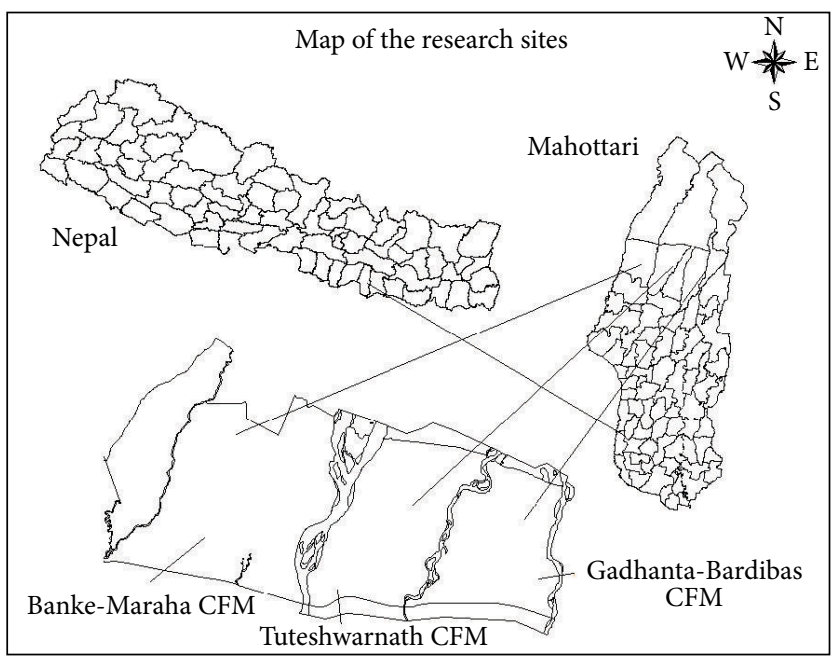

Figure 1: Map of the research site.

the carbon stock and biodiversity are intrinsic components in collaborative forests, their assessment is significant. The records of carbon stock and biodiversity are insufficient in collaborative forests, which justify the need of this study.

Approximately 8000 tree species, or $9 \%$ of the total number of tree species worldwide, are currently under threat of extinction because of forest decline [8] and impacts of climate change. Deforestation continues at an alarming rate which is consequently affecting the biodiversity in the tropics [9]. So, the climate change, deforestation, forest degradation, and biodiversity are interlinked to each other. Of the world's total land surface area, Nepal covers only $0.1 \%$ but harbors 136 ecosystems, about $2 \%$ of the flowering plants, $3 \%$ of the pteridophytes, and $6 \%$ of bryophytes of the world's flora, but 8 species are suspected to be extinct, 1 species is endangered, 7 species are vulnerable, and 31 species fall under the IUCN rare species category [10].

Important elements of REDD+ programme include monitoring, reporting, and verification (MRV) as well as reference emission level (REL) which need sufficient records of carbon stock. Moreover, noncarbon benefit of REDD+ programme has also focused on the biodiversity promotion. Besides, there is another significant growing concern about the relationship between carbon stock and biodiversity: whether working for carbon enhancement through REDD+ programme should include the biodiversity promotion too. Therefore, the research objectives are to assess carbon stock, biodiversity, and their relationship in collaborative forests of Nepal.

\section{Material and Method}

We selected three collaborative forests, namely, BankeMaraha, Tuteshwarnath, and Gadhanta-Bardibas CFMs of Mahottari district, Terai (plain areas), which have areas of 2006, 1334, and 1450 ha, respectively. The reason why these forests were selected for this study is because all three are natural forests (Figure 1), and no such studies have been carried out here. Selected collaborative forests are situated at $26^{\circ} 36^{\prime}$ to $28^{\circ} 10^{\prime} \mathrm{N}$ and $85^{\circ} 41^{\prime}$ to $85^{\circ} 57^{\prime} \mathrm{E}$. The average annual temperature ranges $20-250^{\circ} \mathrm{C}$, and average annual rainfall recorded $1100-3500 \mathrm{~mm}$. The main species of these forests is Sal (Shorea robusta), and other species are Saj (Terminalia tomentosa), Botdhairo (Lagerstroemia parviflora), Harro (Terminalia chebula), and Barro (Terminalia bellirica).

2.1. Sampling Design and Data Collection. Stratified random sampling was applied to gather the biophysical data. So, three main strata specifically regeneration, pole, and tree based on stage of the forest were delineated on the map of the study areas.

The pilot sampling was carried out to calculate the number of sample plots [11]. For this purpose at least 15 sample plots were taken from each stratum of collaborative forests. In this context, the diameter at breast height and height were measured to determine the minimum number of sample plots based on coefficient of variance [12]. Hence, altogether, 96 samples were collected, out of this, 32 samples from Banke-Maraha CFM, 33 samples from Tuteshwarnath CFM, and 31 from Gadhanta-Bardibas CFM.

Firstly, sample plots were distributed on each stratum on the map, and the coordinates of sample plots were uploaded in GPS. Secondly, concentric sample plots were established in the field by navigating the GPS coordinates. For tree stratum $20 \mathrm{~m} \times 25 \mathrm{~m}$ sample plot was laid out, and nested plots for poles $(10 \mathrm{~m} \times 10 \mathrm{~m})$, sapling $(5 \mathrm{~m} \times 5 \mathrm{~m})$, seedling $(5 \mathrm{~m} \times 2 \mathrm{~m})$ and litter, herbs, and grasses $(1 \mathrm{~m} \times 1 \mathrm{~m})$ were laid out simultaneously [13]. Similarly, soil sample plot was laid out at the centre of the plot. The height and diameter at breast height of plants having $\mathrm{dbh}>1 \mathrm{~cm}$ were measured. Then, sapling $(5 \mathrm{~cm}<\mathrm{dbh}>1 \mathrm{~cm})$, seedlings, herbs, and shrubs were counted, and fresh weights of their samples were recorded. Moreover, soil samples were collected from three different depths $0-0.10,0.10-0.30$, and $0.30-0.60 \mathrm{~m}$ in order to determine the soil carbon. In addition, the list of tree species was prepared to assess the biodiversity. 
TABLE 1: Carbon stock in collaborative forests.

\begin{tabular}{|c|c|c|c|c|c|c|}
\hline \multirow{2}{*}{ Collaborative forests } & \multicolumn{2}{|c|}{ Above ground C stock $t$ ha $^{-1}$} & \multicolumn{2}{|c|}{ Below ground C stock $t \mathrm{ha}^{-1}$} & \multirow{2}{*}{ Total $t \mathrm{ha}^{-1}$} & \multirow{2}{*}{ Total C } \\
\hline & LHG & Regeneration + pole + tree & Root & Soil & & \\
\hline Banke-Maraha CFM & 4.21 & 116.72 & 15.12 & 61.06 & 197.10 & 395398 \\
\hline Tuteshwarnath CFM & 3.603 & 139.8 & 17.92 & 61.26 & 222.58 & 296927 \\
\hline Gadhanta-Bardibas CFM & 6.325 & 178.88 & 23.15 & 66.31 & 274.66 & 398268 \\
\hline
\end{tabular}

\subsection{Data Analysis}

2.2.1. Calculation of Carbon. It is essential to calculate the forest biomass before determining the carbon except for soil carbon. Therefore, the above ground tree dry biomass (AGTB in $\mathrm{kg}$ ) was calculated by using $\mathrm{AGTB}=0.0509 x \rho D^{2} \mathrm{H}[14]$ for plants $\mathrm{dbh}>5 \mathrm{~cm}$, where $\rho$ is wood density (g/cc), $D$ is the diameter at breast height $(\mathrm{cm})$, and $H$ is the height of the tree (m).

Biomass of $\mathrm{dbh}<5 \mathrm{~cm}$ was estimated using Tamrakar's [15] equation. This equation only provides the fresh weight, so collected samples were dried in the lab at $105^{\circ} \mathrm{C}$ until samples showed the constant weight: $\operatorname{Ln}(\mathrm{AGSB})=a+b \ln (\mathrm{DBH})$; whereas AGSB is the above ground sapling biomass $(\mathrm{kg})$, $\mathrm{Ln}$ is natural $\log , a$ and $b$ are constants, and $\mathrm{DBH}(\mathrm{cm})$ is diameter at breast height. Similarly, samples of seedling, leaf litter, herbs, and grass (LHG) also dried. Moreover, the root biomass was calculated by using root shoot ratio 0.125 . The biomass was converted into carbon by multiplying with 0.47 [11].

Carbon content in the soil was analyzed by Walkley Black Method [16].

Bulk density (BD g/cc) = (oven dry weight of soil)/ (volume of soil in the corer).

SOC $=$ organic carbon content $\% *$ soil bulk density $(\mathrm{Kg} / \mathrm{cc}) *$ thickens of horizon.

Total carbon $=$ total biomass carbon + soil carbon [17].

2.2.2. Biodiversity Calculation. Biodiversity indices were calculated using following formulae.

Simpson's index $D=\sum n_{i}\left(n_{i}-1\right) / N(N-1)$, where $N$ is the total number of all organisms and $n_{i}$ the numbers of individuals of each individual species.

Simpson's diversity index $=1 / p_{i}^{2}$, where $p_{i}$ is the total individuals in a species community.

Species richness $S$ is the number of species in the community or sample.

Simpson's evenness $E=D / S$, where $D$ is the Simpson's diversity index and $S$ is the species richness.

Shannon-Wiener Biodiversity Index $H=$ $-\sum_{i=1}^{s}\left(p_{i}\right)\left(\ln p_{i}\right)$, where $p_{i}$ is the total individuals in a species community [18].
2.2.3. Relationship between Carbon (Biomass) and Biodiversity. Regression analysis was carried out to find the correlation between carbon stock and biodiversity. For this, only carbon of biomass was used. So, the relationship between carbon and species richness as well as carbon and evenness was developed so that REDD+ policy implication may be worthwhile.

2.2.4. Statistical Analysis. The collected data set of collaborative forests was tested for normality in order to apply one-way ANOVA, Tukey's test by using software SPSS 17. Similarly, the biodiversity differences were also tested using $t$-test [19].

\section{Results and Discussion}

3.1. Comparison of C Stock among Collaborative Forests. Total carbon stock in collaborative forests varied from site to site. It was found that the highest quantity of carbon stock was $274.66 \mathrm{tha}^{-1}$ in Gadhanta-Bardibas CFM while it was lowest about $197.10 t \mathrm{ha}^{-1}$ in Banke-Maraha CFM (Table 1). The reason behind it may be due to various effects of drivers of deforestation and forest degradation. Generally, it was found that loggers of Khayarmara village living near to BankeMaraha CFM illegally trade the timber and firewood. These types of activities are not so common in other CFMs. In addition, uncontrolled grazing and sudden fire also have been affecting the carbon stock in CFMs. Though, no study was carried out regarding the carbon stock in collaborative forests in Nepal, the pilot study done in Kayarkhola Watershed in community forest showed that $276.5 \mathrm{tC} \mathrm{ha}^{-1}$ in the inventory was done in 2011 [20]. It was found different in studies done in Terai Arc Landscape. In the inventory carried out in 2010, there was $206.15 \mathrm{tC} \mathrm{ha}^{-1}$ in government managed forests, $240 \mathrm{tCha} \mathrm{Ch}^{-1}$ in community forests, and $274.58 \mathrm{tCha}^{-1}$ in protected forests. [21]. These results are very close to the findings of this research.

3.2. Comparison of C Stock Variation in Collaborative Forests. The ANOVA $F$ test showed that there was variation in $C$ stock in collaborative forests at $5 \%$ significant level.

There was clear variation in mean carbon stocks in each collaborative forest. The Tukey's HSD showed that the quantity of $\mathrm{C}$ stock of Banke-Maraha, Tuteshwarnath, and Gadhanta-Bardibas CFMs varied with each other at 5\% level of significant (Table 2).

3.3. Relationship between Species Richness and Carbon Stock in CFMs. The result showed that there was positive but 
TABLE 2: Multiple comparisons of C stocks using Tukey HSD test.

\begin{tabular}{|c|c|c|c|c|}
\hline Variation $(I)$ & Variation $(J)$ & Mean difference $(I-J)$ & Std. error & $P$ value \\
\hline \multirow{2}{*}{ Banke-Maraha CFM } & Tuteshwarnath CFM & $-25.29^{*}$ & 1.48 & 0.00 \\
\hline & Gadhanta-Bardibas CFM & $-72.33^{*}$ & 1.50 & 0.00 \\
\hline \multirow{2}{*}{ Tuteshwarnath CFM } & Banke-Maraha CFM & $25.29^{*}$ & 1.48 & 0.00 \\
\hline & Gadhanta-Bardibas CFM & $-47.04^{*}$ & 1.49 & 0.00 \\
\hline \multirow{2}{*}{ Gadhanta-Bardibas CFM } & Banke-Maraha CFM & $72.33^{*}$ & 1.50 & 0.00 \\
\hline & Tuteshwarnath CFM & $47.04^{*}$ & 1.49 & 0.00 \\
\hline
\end{tabular}

${ }^{*}$ The mean difference is significant at the .05 level.

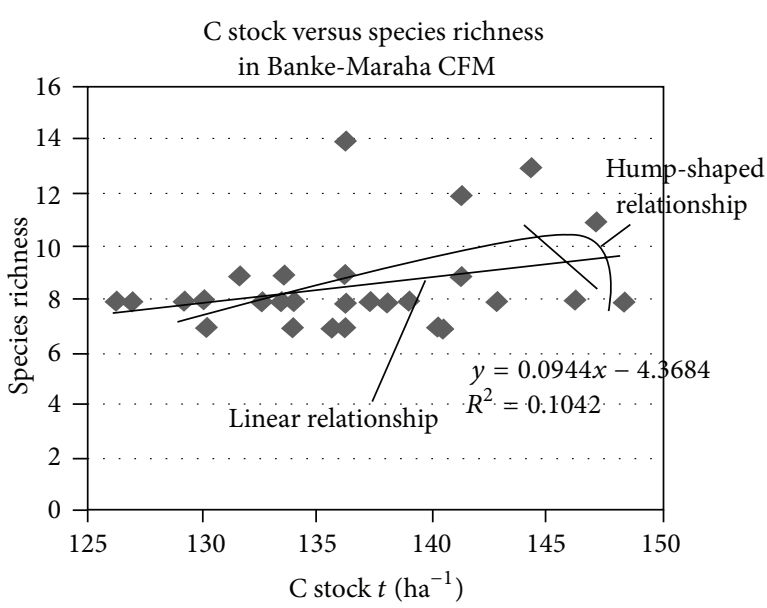

(a)

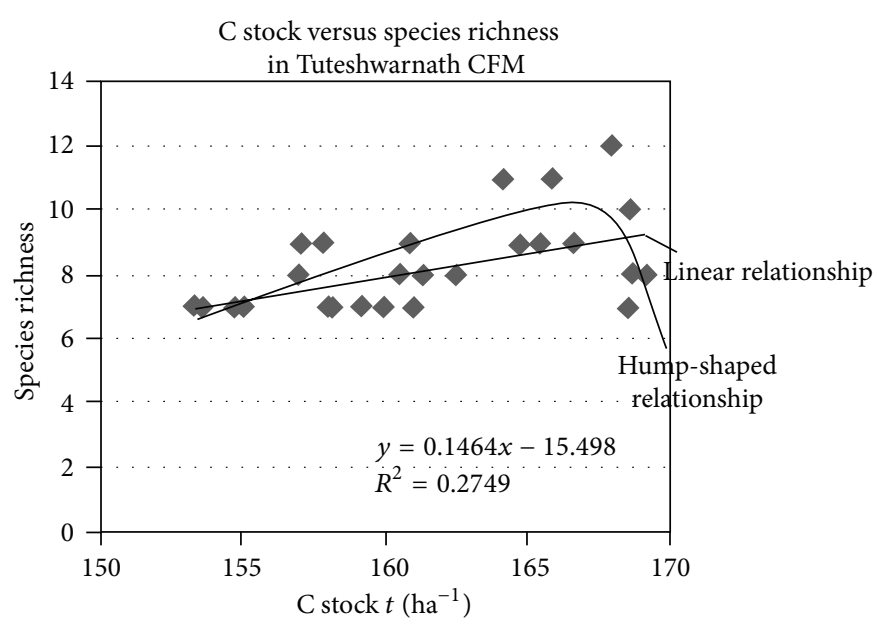

(b)

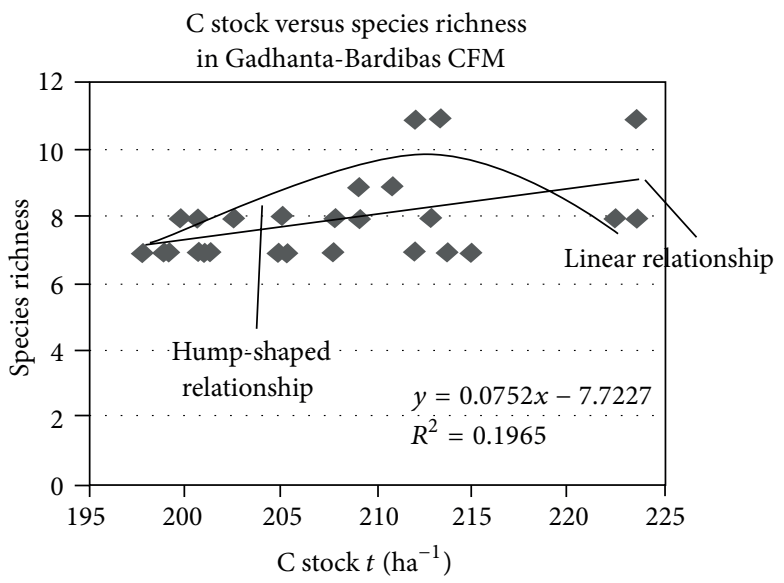

(c)

Figure 2: (a) Relation between species richness and C stock in Banke-Maraha CFM. (b) Relation between species richness and C stock in Tuteshwarnath CFM. (c) Relation between species richness and C stock in Gadhanta-Bardibas CFM.

very weak relationship between carbon stock and species richness of collaborative forests. However, it showed nearly hump-shaped relationship (Figures 2(a)-2(c)). The values of $R^{2}$ of linear regression range from 0.10 to 0.27 . Generally, the variation of carbon stock does not depend upon the species diversification. The research done by Karna [22] also supported this idea. He stated that there is positive but weak relationship between carbon stock and biodiversity, though the hump-shaped relationship existed between them $[23,24]$.
3.3.1. Relationship between Species Richness and Carbon Stock in Banke-Maraha CFM. For more details see Figure 2(a).

3.3.2. Relationship between Species Richness and Carbon Stock in Tuteshwarnath CFM. For more details see Figure 2(b).

3.3.3. Relationship between Species Richness and Carbon Stock in Gadhanta-Bardibas CFM. For more details see Figure 2(c). 
TABLE 3: Biodiversity indices in collaborative forests.

\begin{tabular}{lccc}
\hline Biodiversity indices & Banke-Maraha CFM & Tuteshwarnath CFM & Gadhanta-Bardibas CFM \\
\hline Shannon-Wiener Biodiversity Index & 2.33 & 2.28 & 2.21 \\
Simpson's index & 0.39 & 0.41 & 0.44 \\
Average species richness & 8.45 & 8.12 & 7.94 \\
Simpson's evenness (mean value) & 0.85 & 0.83 & 0.79 \\
\hline
\end{tabular}

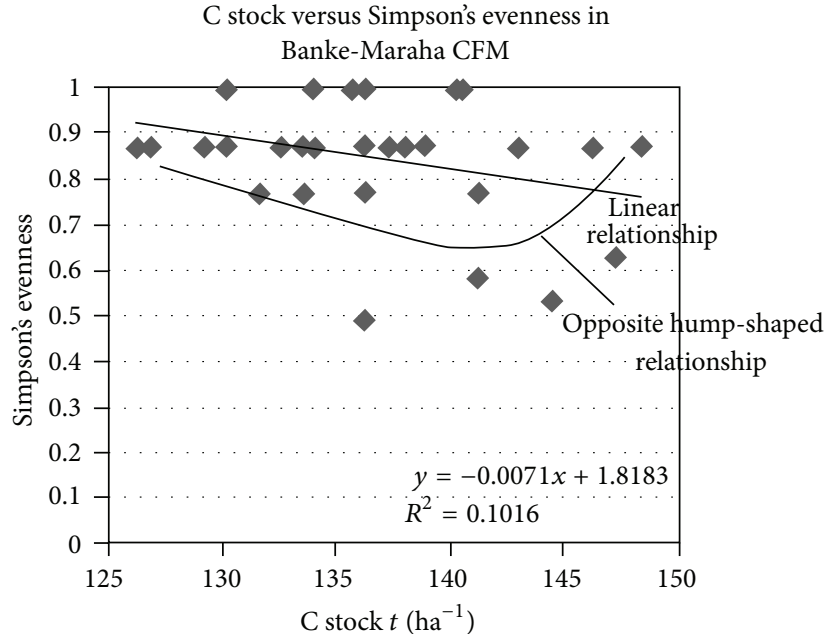

(a)

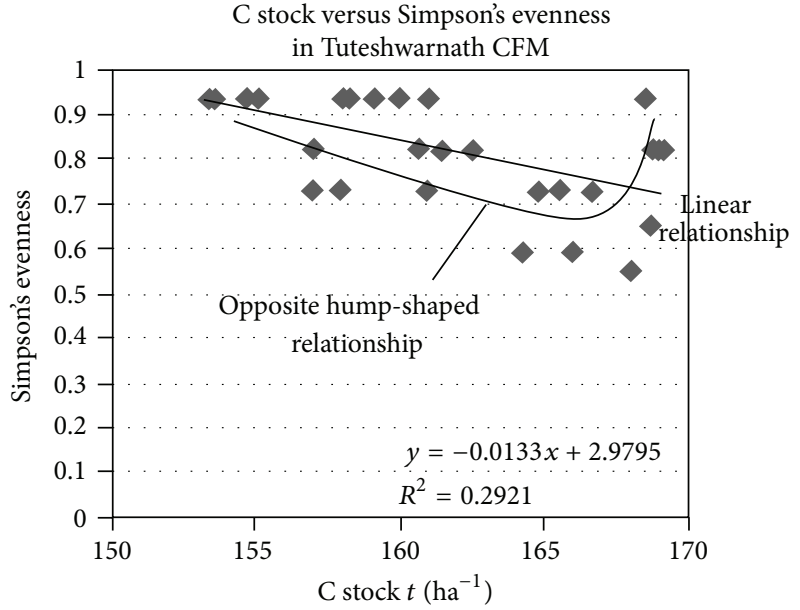

(b)

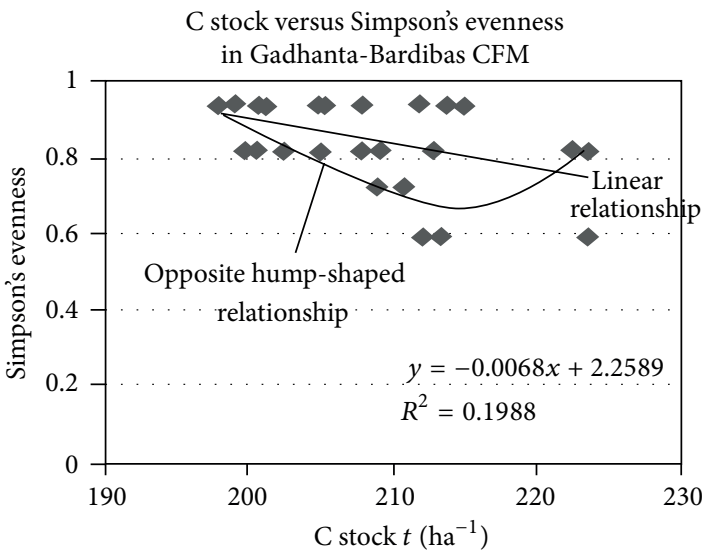

(c)

Figure 3: (a) Relation between Simpson's evenness and C stock in Banke-Maraha CFM. (b) Relation between Simpson's evenness and C stock in Tuteshwarnath CFM. (c) Relation between Simpson's evenness and C stock in Gadhanta-Bardibas CFM.

3.4. Relation between Simpson's Evenness and C Stock. The result showed weak and negative relationship between carbon stock of collaborative forests and Simpson's evenness as the values of $R^{2}$ range from 0.10 to 0.29 . However, the opposite hump-shaped relationship was found between them (Figures $3(\mathrm{a})-3(\mathrm{c}))$. This finding is also supported by the study done by Heather et al. [25].

3.4.1. Relationship between Simpson's Evenness and C Stock in Banke-Maraha CFM. For more details see Figure 3(a).

3.4.2. Relationship between Simpson's Evenness and C Stock in Tuteshwarnath CFM. For more details see Figure 3(b).
3.4.3. Relationship between Simpson's Evenness and C Stock in Gadhanta-Bardibas CFM. For more details see Figure 3(c).

3.5. Variation in Biodiversity in Collaborative Forests. The values of biodiversity indices varied according to collaborative forests (Table 3). The Shannon-Wiener Biodiversity Index was the highest 2.33 in Banke-Maraha CFM, and it was the lowest 2.21 in Gadhanta-Bardibas CFM. This indicates that the highest biodiversity was in Banke-Maraha CFM.

More species diversity was found in the fringe areas of forest types. There are two rivers, namely, Banke river in the west and Maraha in the east. Because of river rain tropical and Shorea robusta mixed forest in Banke-Maraha CFM, it had the highest biodiversity. No management operations except 
for selection felling have been carried out in collaborative forests. The research done by Sapkota et al. [26] in hill Shorea robusta forest showed that values of Shannon-Wiener index and Simpson index were 2.42 and 0.64, respectively, which are close to the value of Shannon Wiener index of Banke-Maraha CFM.

3.6. Comparison of Biodiversity in Collaborative Forests. Statistically, $t$-test showed there was no clear differences in values of Shannon-Wiener indices between Banke-Maraha and Tuteshwarnath CFM, Gadhanta-Bardibas and Tuteshwarnath CFM, and Banke-Maraha and Gadhanta-Bardibas CFM as the $t$-cal $<t$-tab at $5 \%$ significant level. So, it can be reasonably confident that there were no clear variation in Shannon Wiener indices value among (i) Banke-Maraha and Tuteshwarnath CFMs, (ii) Tuteshwarnath and GadhantaBardibas CFMs, and (iii) Gadhanta-Bardibas and BankeMaraha CFMs.

\section{Conclusion and Recommendation}

The highest quantity of carbon stock was found in GadhantaBardibas CFM while it was lowest in Banke-Maraha CFM. There was positive and very weak relationship between carbon stock and species richness of collaborative forests; it showed nearly hump-shaped relationship. However, the opposite hump-shaped relationship was found between values of Simpson's evenness and carbon stock. So, it indicated that the forest carbon enhancement cannot assure the biodiversity conservation and promotion. Therefore, the REDD+ programme should have parallel focus on biodiversity conservation and promotion.

\section{Conflict of Interests}

The authors report no conflict of interests. The authors alone are responsible for the content and writing of the paper.

\section{Acknowledgments}

The authors would like to acknowledge the chairperson of Banke-Maraha collaborative, Mr. Raghunath Prashad Yadav, for his sincere help in field data collection. They are also thankful to the staffs of district forest office like Ram Ashis Yadavand and Ram Jiban Yadav for their help during the field work.

\section{References}

[1] IPCC, Fourth Assessment Report of the Intergovernmental Panel on Climate Change, Intergovernmental Panel on Climate Change, Geneva, Switzerland, 2009.

[2] M. Skutsch and P. E. van Laake, "Redd as multi-level governance in-the-making," Energy and Environment, vol. 19, no. 6, pp. 831844, 2008.

[3] C. Luttrell, L. Loft, M. Gebara, and K. D. Fernada, "Who should benefit and why? Discourses on $\mathrm{REDD}^{+}$benefit sharing," in Analyzing REDD ${ }^{+}$Challenges and Choices, pp. 129-152, CIFOR, Bogor, Indonesia, 2012.
[4] IPCC, Climate Change 2007: Synthesis Report, edited by R. K. Pachauri and A. Resinger, Contribution of Working Groups I, II and III to the Fourth Assessment Report of the Intergovernmental Panel on Climate Change, Intergovernmental Panel on Climate Change, Geneva, Switzerland, 2007.

[5] W.G. Ross and P. A. Sheikh, "Deforestation and Climate Change," Congressional Research Service, 2010.

[6] MOPE, "Initial national communication to the conference of the parties of the united nations framework convention on climate change," Tech. Rep., Ministry of Population and Environment, Singhadurbar, Kathmandu, 2004.

[7] RRI and ITTO, "Tropical forest tenure assessment: trends, challenges and opportunities," Rights and Resources Institute and International Tropical Timber Organization, 2009.

[8] S. P. Singh, P. P. Sah, V. Tyagi, and B. S. Jina, "Species diversity contributes to productivity-evidence from natural grassland communities of the Himalaya," Current Science, vol. 89, no. 3, pp. 548-552, 2005.

[9] FAO, "Global forest resources assessment," Main Report, FAO Forestry Paper, 2010.

[10] MFSC, National Biodiversity Action Plan, Ministry of Forests and Soil Conservation, HMG of Nepal, Global Environment Forum, UNDP, 2000.

[11] K. G. Macdicken, A Guide to Monitoring Carbon Storage in Forestry and Agroforestry Projects, Winrock International Institute for Agricultural Development, Arlingt, Va, USA, 1997.

[12] S. D. Moore and G. P. Maccabe, Introduction to the Practice of Statistics, M.H. Freeman and Company, New York, NY, USA, 2003.

[13] DOF, Community Forestry Inventory Guideline, Community Forests Division, Department of Forests, Kathmandu, Nepal, 2003.

[14] J. Chave, C. Andalo, S. Brown et al., "Tree allometry and improved estimation of carbon stocks and balance in tropical forests," Oecologia, vol. 145, no. 1, pp. 87-99, 2005.

[15] P. R. Tamrakar, Biomass and Volume Tables with Species Description for Community Forest Management, Ministry of Forests and Soil Conservation, Kathmandu, Nepal, 2000.

[16] A. E. Walkley and J. A. Black, "An examination of the method for determining soil organic method, and proposed modification of the Chromic acid Titration method," Soil Science, vol. 37, pp. 29-38, 1958.

[17] E. R. Mini and Y. S. Rao, "An evaluation of soil carbon sequestration in teak and ecalypt plantations," NeBIO, vol. 2, no. 3, pp. 9-11, 2011.

[18] J. Barlow, T. A. Gardner, and I. S. Araujo, "Quantifying the biodiversity value of tropical primary, secondary, and plantation forests," Proceedings of the National Academy of Sciences of the United States of America, vol. 104, no. 47, pp. 18555-18560, 2007.

[19] J. I. Rocky and C. Miligo, "Regeneration pattern and size-class distribution of indigenous woody species in exotic plantation in Pugu Forest Reserve, Tanzania," International Journal of Biodiversity and Conservation, vol. 4, no. 1, pp. 1-14, 2012.

[20] E. Rana, Processes and Experiences in REDD Pilot Project in Nepal, International Centre for Integrated Mountain Development, Kathmandu, Nepal, 2011.

[21] Y. Manandhar, REDD Readiness and Monitoring, Reporting and Verification: Lesson Learned from Field, World Wildlife Fund, Kathmandu, Nepal, 2010.

[22] Y. K. Karna, Mapping above ground carbon using world view satellite image and lidar data in relationship with tree diversity 
and forests [M.S. thesis], University of Twente, Enschede, The Netherlands, 2012.

[23] W. Wang, L. Xiangdong, D. K. Daniel, and C. Peng, "Positive relationship between aboveground carbon stocks and structural diversity in spruce-dominated forest stands in brunswick, Canada," Forest Science, vol. 57, no. 6, pp. 506-515, 2011.

[24] Q. Guo, "The diversity-biomass-productivity relationships in grassland management and restoration," Basic and Applied Ecology, vol. 8, no. 3, pp. 199-208, 2007.

[25] D. V. Heather, R. W. Michael, B. C. Stephen, E. L. Ariel, and N. S. Frederick, "Relationship between abovegroundbiomass and multiple measures of biodiversity in subtropical Forest of Puerto Rico," Biotropica, vol. 42, no. 3, pp. 290-299, 2010.

[26] I. P. Sapkota, M. Tigabu, and P. C. Oden, Tree Diversity and Regeneration of Community-Managed Bhabar Lowland and Hill Sal Forests in Central Region of Nepal, Swedish University of Agricultural Sciences Southern Swedish Forest Research Centre, Alnarp, Sweden, 2009. 

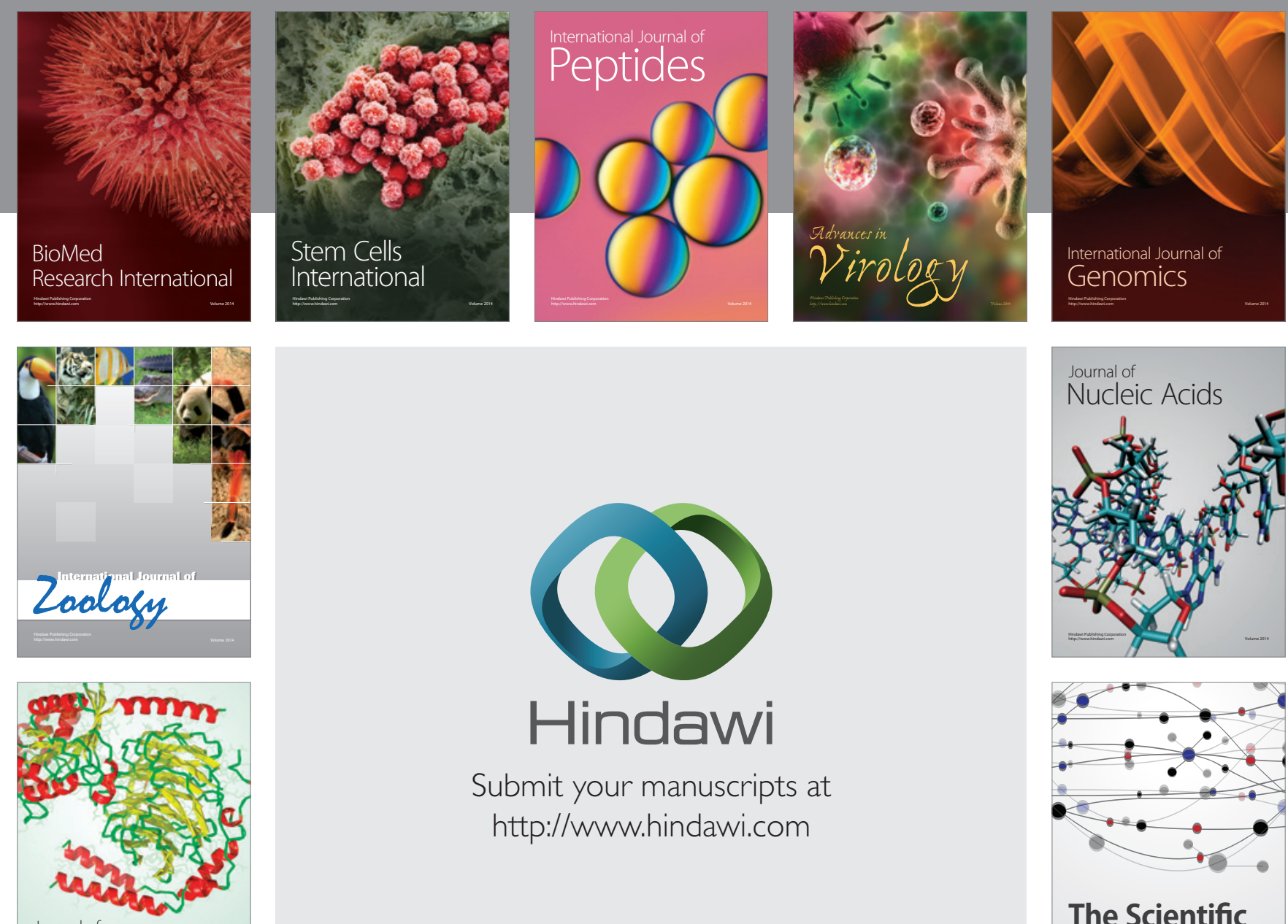

Submit your manuscripts at

http://www.hindawi.com

Journal of
Signal Transduction
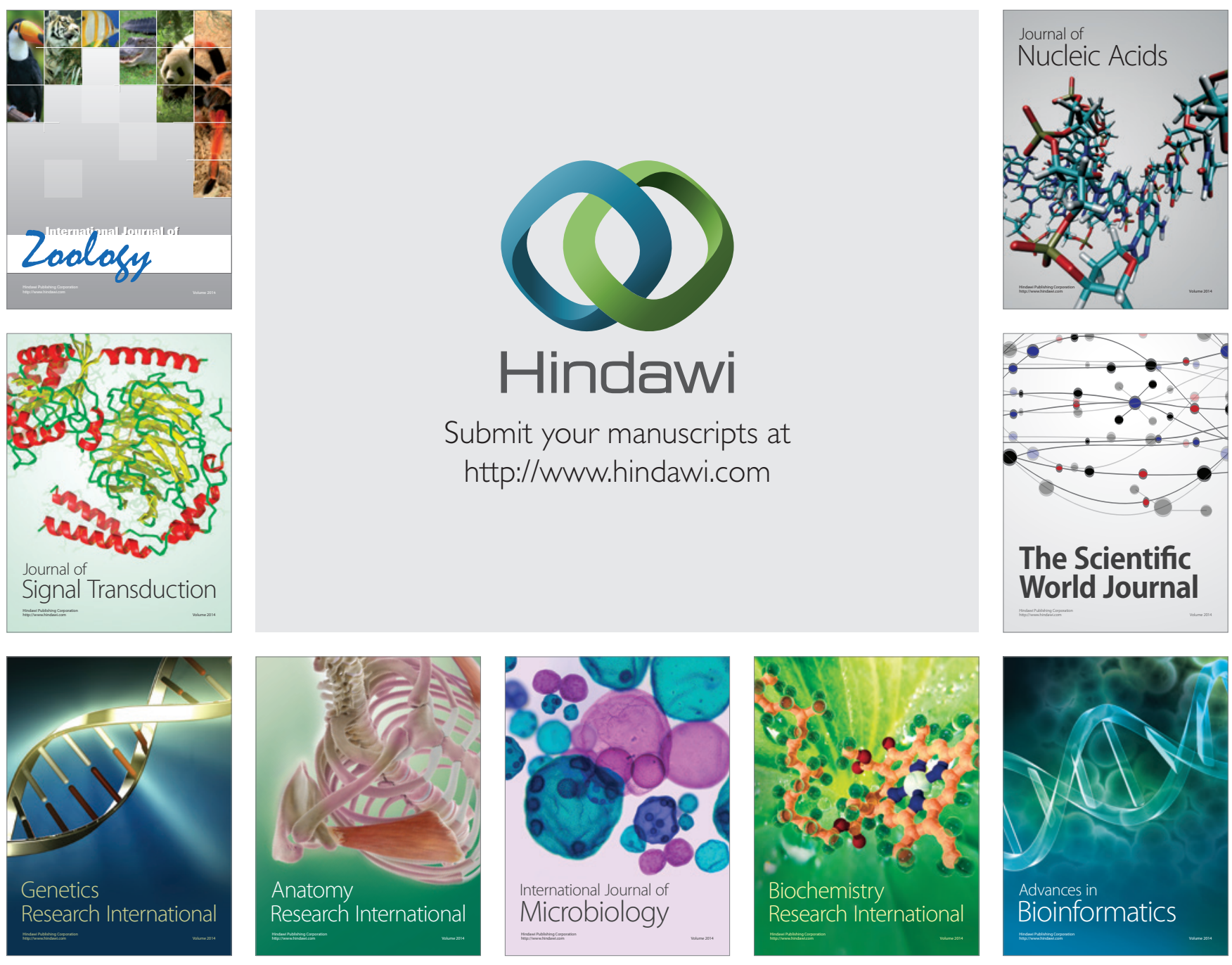

The Scientific World Journal
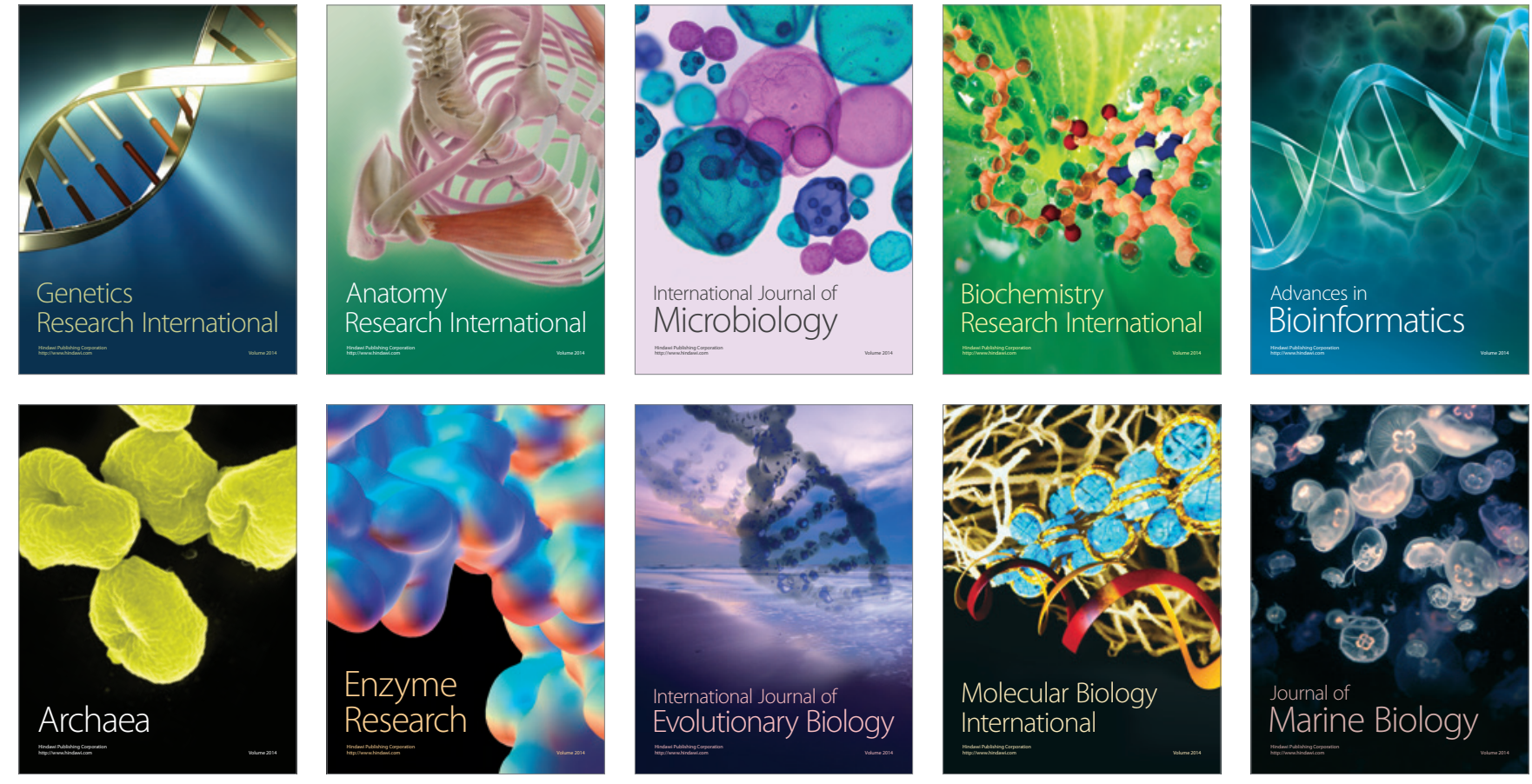